\title{
Pengaruh Harga Dan Kualitas Pelayanan Terhadap Minat Beli Konsumen Pada Fotocopy Anugrah Rengat
}

\author{
Hermanto, Angga Hapsila \\ Dosen Sekolah Tinggi Ilmu Indragiri Rengat, Indonesia \\ hermanto@stieindragiri.ac.id
}

\begin{abstract}
Abstrak
Penelitian ini bertujuan untuk mengungkapkan pengaruh harga dan kualitas pelayanan tehradap minat beli konsumen pada Fotocopy Anugrah Rengat. Dengan jumlah sampel dalam penelitian sebanyak 98 orang, metode pengambilan sampel dengan accidental sampling secara acak. Metode pengolahan data menggunakan bantuan Program Aplikasi IBM SPPS Statistics 21, Analisis data yang digunakan dengan Uji Instrumen (Uji Validitas, Uji Reliabilitas), Uji Asumsi Klasik (Uji Normalitas, Uji Linearitas, Uji Heterokedastisitas, Uji Multikolinearitas), Regresi Linear Berganda, Korelasi Berganda, Koefesien Determinasi dan Uji Hipotesis dengan uji F serta uji t. Hasil penelitian di dapatkan adalah (1) Harga secara parsial berpengaruh signifikan terhadap minat beli pada Fotocopy Anugrah Rengat. (2) Kualitas pelayanan secara parsial berpengaruh signifikan terhadap minat beli pada Fotocopy Anugrah Rengat. (3) Harga dan kualitas pelayanan secara simultan berpengaruh signifikan terhadap minat beli pada Fotocopy Anugrah Rengat. Besarnya pengaruh dari kedua variabel harga kualitas pelayanan terhadap minat beli sebesar 20,6\%, sedangkan sisanya dipengaruhi oleh variabel lain yang tidak diteliti dalam penelitian ini sebesar 79,4\%. Akhir penelitian penulis menyarankan kepada pemilik usaha untuk memperhatikan harga yang dijual dengan memberikan potongan dan diskon kepada konsumen yang berbelanja, pemilik usaha perlu melakukan breafing kepada karyawan untuk meningkatkan kualitas pelayanan yang diberikan dengan memberikan pelayanan yang ramah dan memberikan senyuman kepada setiap konsumen.
\end{abstract}

Kata Kunci : Harga, Kualitas Pelayanan dan Minat Beli

\section{Pendahuluan}

Usaha fotocopy banyak sekali diminati oleh pelaku usaha yang meinvestasikan dananya dalam kegiatan usaha. Dikecamatan rengat sendiri banyak usaha pofotocopy, dalam melakukan usaha fotocopy pelaku usaha juga melakukan penjualan atk beserta pulsa. Setiap harinya ada saja masyarakat yang membutuhkan fotocopy, hal ini tentu membuat pelaku usaha bagaimana menarik hati pelanggan untuk menggunakan jasa fotocopynya. Dari data Dinas Perindustrian dan Perdagangan Kabupaten Indragiri Hulu bahwa di Kecamatan Rengat dari tahun 2015 s/d 2018 terdapat peningkatan pelaku usaha fotocopy. Berikut jumlah pelaku usaha fotocopy pada kecamatan rengat tahun $2015 \mathrm{~s} / \mathrm{d} 2018$

Tabel 1. Jumlah Pelaku Usaha Fotocopy di Kecamatan Rengat

\begin{tabular}{ccc}
\hline No & Tahun & Jumlah Pelaku Usaha \\
\hline 1 & 2015 & 28 Pelaku Usaha \\
2 & 2016 & 35 Pelaku Usaha \\
3 & 2017 & 41 Pelaku Usaha \\
4 & 2018 & 49 Pelaku Usaha \\
\hline
\end{tabular}

Perkembangan usaha fotocopy yang semakin meningkat setiap tahunnya tidak terlepas dari kebutuhan masyarakat untuk jasa fotocopy dalam keperluan sehari-harinya. Minat beli 
konsumen menjadi salah satu faktor pendukung pelaku usaha untuk membuka usaha fotocopy.

Fotocopy anugrah merupakan salah satu fotocopy yang ada di kecmatan rengat. Minat beli konsumen pada fotocopy anugrah mengalami fluaktuasi setiap tahunnya. Dengan meningkat jumlah pelaku usaha setiap tahunnya, tentu membuat pemilik usaha seperti fotocopy anugrah untuk memenangkan pesaingan usaha dalam minat beli konsumen menjadi pertimbangan yang harus dilakukan. Berikut jumlah pendapatan yang diterima fotocopy anugrah tahun $2015 \mathrm{~s} / \mathrm{d} 2018$.

Tabel 2. Jumlah Pendapatan

\begin{tabular}{ccc}
\hline No & Tahun & Jumlah Pendapatan \\
\hline 1 & 2015 & Rp. 390.114.000 \\
2 & 2016 & Rp. 478.378.000 \\
3 & 2017 & Rp. 421.923.000 \\
4 & 2018 & Rp. 385.745.000 \\
\hline
\end{tabular}

Minat beli konsumen pada Fotocopy Anugrah yang mengalami flutukasi setiap tahunnya. Minat beli konsumen yang mengalami penurunan hal ini tentu menjadi masalah bagi usaha yang dijalankan oleh pelaku bisnis. Berbagai upaya telah dilakukan oleh pelaku usaha untuk meningkatkan minat beli konsumen dengan memberikan harga yang sesuai dengan pasaran, selain itu pelaku usaha juga memberikan pelayanan yang prima kepada setiap konsumen.

Adapun tujuan penelitian ini untuk mengetahui dan menguji secara empirik : (1) Pengaruh harga secara parsial terhadap minat beli konsumen pada Fotocopy Anugrah Rengat, (2) Pengaruh kualitas pelayanan secara parsial terhadap minat beli konsumen pada Fotocopy Anugrah Rengat, (3) Pengaruh harga dan kualitas pelayanan secara parsial terhadap minat beli konsumen pada Fotocopy Anugrah Rengat.

\section{Tinjauan Pustaka}

\section{Minat Beli}

Menurut Gunarso yang dikutip oleh [1], Minat merupakan salah satu aspek psikologis yang mempunyai pengaruh cukup besar terhadap perilaku dan minat juga merupakan sumber motivasi yang akan mengarahkan seseorang dalam melakukan apa yang mereka lakukan, selain itu minat juga dapat diartikan sebagai sesuatu yang pribadi dan berhubungan dengan sikap, individu yang berminat terhadap suatu obyek akan mempunyai kekuatan atau dorongan untuk melakukan seorangkaian tingkah laku untuk mendekati atau mendapatkan objek tersebut.

Jadi minat beli disini merupakan keinginan dan kemauan dari seorang konsumen untuk memutuskan membeli suatu produk dari yang dijual dengan pemilik usaha.

\section{Harga}

Menurut Basu Swasta yang dikutip oleh [2], harga merupakan sejumlah uang yang harus dibayar oleh konsumen atau pembeli untuk mendapatkan produk yang ditawarkan oleh penjual.

Jadi harga merupakan hal yang harus dibayarkan oleh seorang konsumen untuk produk yang akan mereka miliki.

Kualitas Pelayanan

Menurut basu swasta yang dikutip oleh [3], Pelayanan merupakan salah satu faktor internal yang sangat menentukan keberhasilan suatu usaha dalam melayani konsumen.

Jadi kualitas pelayanan merupakan apa yang diterima oleh konsumen dan dirasakan pada saat itu, seperti pelayanan yang cepat, ramah dan mudah senyum oleh penjual. 


\section{Metodologi Penelitian \\ Objek Penelitian}

Kegiatan penelitian ini dilakukan pada Fotocopy Anugrah Rengat. Beralamatkan Jl. Datuk Hasyim kelurahan Kampung Besar Seberang Kecamatan Rengat.

\section{Desain Penelitian}

Pada penelitian ini menggunakan metode kuantitatif, menurut Sugiyono (2014:8), metode kuantitatif adalah metode yang berlandasan pada filsafat positifisme, digunakan untuk meneliti pada populasi dan sampel tertentu, pengumpulan data menggunakan instrumen penelitian, analisis data bersifat kuantitatif/statistik dengan tujuan untuk menguji hipotesis yang telah ditetapkan. Dengan jumlah sampel penelitian ini sebanyak 98 orang.

\section{Hasil dan Pembahasan}

\section{Analsisis Regresi Linear Berganda}

Untuk mengetahui pengaruh variabel bebas terhadap Minat Beli Konsumen pada Fotocopy Anugrah Rengat dilakukan pengujian Hipotesis dengan menggunakan beberapa analisis statistik. Dari hasil pengolahan data, maka diperoleh koefisien regresi dan dapat dilihat pada tabel berikut:

Tabel 3. Hasil Regresi Berganda Variabel Harga $\left(\mathrm{X}_{1}\right)$, Kualitas pelayanan $\left(\mathrm{X}_{2}\right)$ dan Minat Beli (Y)

Coefficients $^{\mathrm{a}}$

\begin{tabular}{|l|r|r|r|r|r|}
\hline \multirow{2}{*}{ Model } & \multicolumn{2}{|c|}{$\begin{array}{c}\text { Unstandardized } \\
\text { Coefficients }\end{array}$} & $\begin{array}{c}\text { Standardized } \\
\text { Coefficients }\end{array}$ & \multirow{2}{*}{ Sig. } \\
\cline { 2 - 4 } & \multicolumn{1}{|c|}{ B } & \multicolumn{1}{c|}{ Std. Error } & \multicolumn{1}{c|}{ Beta } & & \\
\hline \multirow{2}{*}{$\begin{array}{l}\text { (Constant) } \\
1\end{array}$ Harga } & 3.790 & 2.347 & & 1.615 & .110 \\
Kualitas & .328 & .088 & .341 & 3.734 & .000 \\
Pelayanan & .234 & .076 & .283 & 3.098 & .003 \\
\hline
\end{tabular}

Sumber : Data Olahan IBM SPSS Versi 21.0

Berdasarkan hasil olahan data di atas, maka diperoleh persamaan sebagai berikut : $\mathrm{Y}=3,790+0,328 \mathrm{X} 1+0,234 \mathrm{X} 2$

Keterangan :

$$
\begin{array}{ll}
\mathrm{Y} & =\text { Minat Beli } \\
\mathrm{a} & =\text { Konstanta } \\
\mathrm{X} 1 & =\text { Harga } \\
\mathrm{X} 2 & =\text { Kualitas Pelayanan }
\end{array}
$$

Dari hasil perhitungan dan persamaan analisis statistik koefisien regresi linear berganda di atas, maka dapat diartikan:

a. Nilai konstanta $(\mathrm{a}=3,790)$, merupakan konstanta apabila semua nilai variabel Harga $\left(\mathrm{X}_{1}\right)$ dan Kualitas Layanan $\left(\mathrm{X}_{2}\right)$ sama dengan 0, maka nilai variabel Minat Beli (Y) sebesar 7,431.

b. Nilai koefisien Harga $\left(X_{1}=0,328\right)$. Artinya jika variabel Harga $\left(X_{1}\right)$ mengalami/peningkatan 1 satuan dan Kualitas Layanan $\left(\mathrm{X}_{2}\right)$ tetap, maka Minat Beli akan meningkat sebesar 0,328. Koefisien bernilai positif artinya terjadi hubungan yang positif antara Harga dengan Minat Beli.

c. Nilai koefisien Promosi $(\mathrm{X} 2=0,234)$. Artinya jika variabel Kualitas Layanan $\left(X_{2}\right)$ mengalami/peningkatan 1 satuan dan variabel Harga $\left(X_{1}\right)$ tetap, maka 
Minat Beli akan meningkat sebesar 0,234. Koefisien bernilai positif artinya terjadi hubungan yang positif antara Kualitas Pelayanan dengan Minat Beli.

\section{Analisis Koefesien Determinasi (Uji $\mathbf{R}^{\mathbf{2}}$ )}

Berdasarkan hasil perhitungan regresi linear berganda dengan menggunakan bantuan program statistik IBM SPSS versi 21.0 maka diperoleh koefisien korelasi berganda seperti yang terdapat pada tabel berikut.

Tabel 4. Hasil Uji Koefesien Determinasi $\left(\mathrm{Uji}^{2}{ }^{2}\right)$ Model Summary

\begin{tabular}{|l|c|c|c|c|}
\hline Model & $\mathrm{R}$ & $\mathrm{R}$ Square & $\begin{array}{c}\text { Adjusted } \mathrm{R} \\
\text { Square }\end{array}$ & $\begin{array}{c}\text { Std. Error Of the } \\
\text { Estimate }\end{array}$ \\
\hline 1 &, $472^{\mathrm{a}}$ &, 223 &, 206 & 1,66339 \\
\hline
\end{tabular}

Sumber : Data Olahan IBM SPSS Versi 21.0

Berdasarkan tabel di atas juga dapat terlihat koefisien determinasi $\left(\mathrm{R}^{2}\right)$. Dari tabel model summary tersebut dapat diketahui nilai Adjusted $\mathrm{R}$ Square adalah 0,206. Jadi, sumbangan pengaruh dari variabel independent (Harga dan Kualitas Pelayanan) terhadap variabel dependent (Minat Beli) sebesar 20,6\%, sedangkan sisanya sebesar $79,4 \%$ dipengaruhi oleh variabel lain yang tidak diteliti dalam penelitian ini.

\section{Uji Parsial}

$$
\begin{aligned}
\text { Df } & =\alpha / 2 ; \mathrm{n}-\mathrm{k} \\
& =0,05 / 2 ; 98-3 \\
& =0,025 ; 95 \\
& =1.98525
\end{aligned}
$$

\section{a. Pengaruh Harga Terhadap Minat Beli}

Untuk variabel harga, diperoleh $\mathrm{t}_{\text {hitung }} 3,734>\mathrm{t}_{\text {tabel }} 1.98525$ atau Sig $0,000<\alpha$ 0,05. Berdasarkan kriteria pengujian data dapat diketahui bahwa $\mathrm{H}_{0}$ ditolak dan $\mathrm{H}_{\mathrm{a}}$ diterima, artinya harga secara parsial berpengaruh terhadap Minat Beli.

\section{b. Pengaruh Kualitas Pelayanan Terhadap Minat Beli}

Untuk variabel Kualitas Pelayanan, diperoleh $\mathrm{t}_{\text {hitung }} 3,098>\mathrm{t}_{\text {tabel }} 1.98525$ atau Sig $0,003<\alpha 0,05$. Berdasarkan kriteria pengujian data dapat diketahui bahwa $\mathrm{H}_{0}$ ditolak dan $\mathrm{H}_{\mathrm{a}}$ diterima, artinya kualitas pelayanan secara parsial berpengaruh terhadap Minat Beli.

Jadi dalam penelitian ini, semua variabel independen (harga dan kualitas pelayanan) secara parsial berpengaruh signifikan terhadap variabel dependen (Minat Beli).

\section{Uji Simultan}

Hasil perhitungan $\mathrm{F}$ hitung dengan program IBM SPSS Versi 21.0 dan perbandingan dengan $\mathrm{F}$ tabel adalah sebagai berikut. 
Tabel 5 . Tabel ANOVA

\begin{tabular}{|rl|r|r|r|r|l|}
\hline & Model & \multicolumn{1}{|c|}{$\begin{array}{c}\text { Sun Of } \\
\text { Squares }\end{array}$} & \multicolumn{1}{c|}{ Df } & $\begin{array}{c}\text { Mean } \\
\text { Square }\end{array}$ & F & Sig. \\
\hline 1 & Regression & 75.321 & 2 & 37.661 & 13.611 & $.000^{\mathrm{b}}$ \\
& Residual & 262.852 & 95 & 2.767 & & \\
& Total & 338.173 & 97 & & & \\
\hline
\end{tabular}

Sumber : Data Olahan IBM SPSS Versi 21.0

Dari tabel hasil perhitungan di atas, dapat diketahui bahwa $\mathrm{F}$ hitung sebesar 13,611 dan $\mathrm{F}$ tabel dengan taraf signifikan 5\%.

$$
\begin{aligned}
& \text { df } 1=\mathrm{k}-1=3-1=2 \\
& \text { df2 }=\mathrm{n}-\mathrm{k}=98-3=95 \\
& \text { maka } \mathrm{F} \text { tabel dari df } 1 ; \text { df } 2=2 ; 95=3,09
\end{aligned}
$$

Diperoleh nilai $F_{\text {hitung }} 13,611>F_{\text {tabel }} 3,09$ atau Sig $0,000<\alpha 0,05$, maka berdasarkan kriteria pengujian data dapat diketahui bahwa $\mathrm{H}_{0}$ ditolak dan $\mathrm{H}_{\mathrm{a}}$ diterima, artinya Harga dan Kualitas Pelayanan secara bersama-sama (simultan) berpengaruh terhadap Minat Beli.

\section{Pembahasan}

\section{Pengaruh Harga dan Kualitas Pelayanan terhadap Minat Beli}

Harga dan Kualitas Pelayanan berpengaruh terhadap minat beli pada Usaha Fotocopy Anugrah karena $F_{\text {hitung }} 13,611>F_{\text {tabel }} 3,09$ atau Sig $0,000<\alpha 0,05$, apabila pelaku usaha memperhatikan kedua faktor ini dalam minat beli konsumen maka pendapatan dari pelaku usaha akan meningkat. Penelitian ini juga sejalan dengan penelitian yang dilakukan [4] dimana penelitian yang berjudul pengaruh harga dan kualitas pelayanan terhadap minat beli ulang, hasil penelitian menunjukan secara Bersama-sama variabel harga dan kualitas pelayanan berpengaruh terhadap minat beli. Selanjutnya penelitian yang dilakukan penelitian sejalan dengan penelitian yang dilakukan [5] dengan judul pengaruh kualitas pelayanan dan harga terhadap minat beli jasa Go-Jek, hasil penelitian menunjukan secara Bersama-sama variabel kualitas pelayanan dan harga berpengaruh terhadap harga dan kualitas pelayanan terhadap minat beli.

Dengan begitu, terlihat bahwa harga dan kualitas pelayanan sangat penting dalam suatu minat beli konsumen, dengan memperhatikan faktor-faktor minat beli ini, tentu sebagai pelaku usaha nantiknya akan bisa mempertahankan usaha yang dijalankannya, selain itu minat beli yang tinggi tentu akan berdampak pada peningkatan omset bagi pelaku usaha.

\section{Pengaruh Harga terhadap Minat Beli}

Harga berpengaruh terhadap minat beli pada usaha Fotocopy Anugrah karena $t_{\text {hitung }} 3,734>$ $t_{\text {tabel }} 1.98525$ atau Sig $0,000<\alpha 0,05$, harga yang ditawarkan di fotocopy anugrah telah sesuai dengan yang diharapkan konsumen maka dari itu sebagai pelaku usaha tentunya agar dapat memberikan potongan kepada konsumen yang loyal dan berbelanja yang banyak di Fotocopopy Anugrah, penelitian ini juga sejalan dengan penelitian yang dilakukan [6] dengan judul Pengaruh Produk Dan Harga Terhadap Minat Beli Konsumen Dalam Berbelanja Produk Kopi Secara Daring : Studi Kasus Pada Situs Internet Otten Coffee, dengan hasil penelitian menunjukan harga secara parsial berpengaruh terhadap minat beli. Selanjutnya penelitian juga sejalan yang dilakukan [7] dengan judul Pengaruh Kualitas Produk Dan Harga Terhadap Minat Beli Konsumen Produk Kosmetik Wardah, hasil penelitian menunjukan harga secara parsial berpengaruh terhadap minat beli. Selanjutnya penelitian juga sejalan yang dilakukan [8] dengan judul Pengaruh Harga, Promosi, dan Kualitas Produk Terhadap Minat Beli Konsumen Pada Perusahaan a-36, hasil penelitian menunjukan harga secara parsial berpengaruh terhadap minat beli. Selanjutnya penelitian juga sejalan yang dilakukan [9] dengan judul Pengaruh Harga Terhadap Minat Beli (Studi 
Kasus Pada Pt Asuransi Jiwa Recapital Di Jakarta), hasil penelitian menunjukan harga secara parsial berpengaruh terhadap minat beli. Selanjutnya penelitian juga sejalan yang dilakukan [10] dengan judul Pengaruh Harga Dan Kualitas Produk Terhadap Minat Beli Sayuran Organik Di Pasar Sambas Medan, hasil penelitian menunjukan harga secara parsial berpengaruh terhadap minat beli.

Sebagai pelaku usaha dalam menjual produk yang dijual harus memperhatikan harga yang diterima konsumen, penjual perlu memperhatikan harga jual dari produk, dengan melakukan penetapan harga yang sesuai agar nantiknya perputaran produk yang dijual semakin tinggi, selain, dengan memberikan potongan harga akan membuat minat beli konsumen akan lebih meningkat.

\section{Kualitas Pelayanan terhadap Minat Beli}

Kualitas Pelayanan berpengaruh terhadap minat beli pada usaha Fotocopy Anugrah karena diperoleh $\mathrm{t}_{\text {hitung }} 3,098>\mathrm{t}_{\text {tabel }} 1.98525$ atau Sig $0,003<\alpha 0,05$ terlihat bahwa kualitas pelayanan itu berpengaruh terhadap minat beli konsumen, selain itu kualitas pelayanan yang diberikan oleh Fotocopy Anugrah masih belum maksimal hal ini terlihat bahwa pada saat pelanggan yang ramai pada toko anugrah pemilik usaha terkadang lambat atau tidak mengacuhkan konsumen dalam berbelanja sehingga konsumen akan pergi ketempat lain untuk berbelanja, penelitian ini juga sejalan dengan penelitian yang dilakukan [11] dengan judul Relaxister Terhadap Minat Beli Secara Online, dengan hasil penelitian menunjukan kualitas pelayanan berpengaruh terhadap minat beli. Selanjutnya penelitian juga sejalan yang dilakukan [12] dengan judul Pengaruh Kualitas Pelayanan Terhadap Kepuasan dan Minat Beli Konsumen di Rumah Makan Boga-Bogi Surakarta, hasil penelitian menunjukan kualitas pelayanan berpengaruh terhadap minat beli. Selanjutnya penelitian juga sejalan yang dilakukan [13] dengan judul pengaruh kualitas produk dan kualitas pelayanan terhadap minat beli ulang pelanggan shao kao kertajaya melalui kepuasan pelanggan, hasil penelitian menunjukan kualitas pelayanan berpengaruh terhadap minat beli. Selanjutnya penelitian juga sejalan yang dilakukan [14] dengan judul pengaruh kulatias pelayanan dan promosi terhadap minat beli ulang jasa service motor dengan kepuasan pelanggan sebagai variabel mediasi ( Studi Pada Bengkel Motor Ahass Cabang UMS), hasil penelitian menunjukan kualitas pelayanan berpengaruh terhadap minat beli. [15] dengan judul pengaruh kualitas pelayanan terhadap minat pembelian ulang (Studi pada Trans Retail Carrefour di Bandung), dengan hasil penelitian menunjukan kualitas pelayanan terhadap minat beli.

Terlihat bahwa kualitas pelayanan berpengaruh terhadap minat beli. Sebagai pelaku usaha, perlu memperhatikan kualitas pelayanan yang diberikan kepada konsumen. Karena kualitas pelayanan yang diberikan akan memberikan kesan tertentu bagi konsumen untuk membeli ulang di usaha yang dijalankan. Kualitas layanan yang diberikan dengan menyapa kepada setiap konsumen yang berbelanja, memberikan senyuman dan bisa menjawab setiap apa yang dibutuhkan konsumen.

\section{Kesimpulan}

Berdasarkan hasil penelitian yang dikemukan diatas, maka dapat disimpulkan beberapa hal penting dalam penelitian ini yaitu :

a. Harga dengan diperoleh $\mathrm{t}_{\text {hitung }} 3,734>\mathrm{t}_{\text {tabel }} 1.98525$ atau Sig $0,000<\alpha 0,05$. sehingga harga secara parsial berpengaruh signifikan terhadap Minat Beli.

b. Kualitas Pelayanan dengan diperoleh 3,098 $>t_{\text {tabel }} 1.98525$ atau Sig 0,003 $<\alpha 0,05$. sehingga kualitas pelayanan secara parsial berpengaruh signifikan terhadap Minat Beli.

c. Diperoleh $F_{\text {hitung }} 13,611>F_{\text {tabel }} 3,09$ atau Sig $0,000<\alpha 0,05$, sehingga Harga dan Kualitas Pelayanan secara bersama-sama (simultan) berpengaruh terhadap Minat Beli. 


\section{DAFTAR PUSTAKA}

[1] J. Retnowulan, "Pengaruh Kualitas Produk dan Persepsi Harga Terhadap Minat Beli Smartphone Xiaomi," Cakrawala, vol. XVII, no. 2, pp. 139-145, 2017.

[2] H. Hermanto, "Pengaruh Persaingan Dan Harga Terhadap Keputusan Pembelian Sepeda Motor Pada Cv. Greentech Belilas Kabupaten Indragiri Hulu," Jmbi, vol. 7, no. 2, pp. 54-63, 2018.

[3] T. Fitrio, "ANALISIS FAKTOR FAKTOR YANG MEMPENGARUHI KEPUTUSAN KONSUMEN MEMILIH MINIMARKET SEBAGAI TEMPAT BERBELANJA PADA MINIMARKET DI KOTA RENGAT,” Jmbi, vol. VII, no. 04, pp. 155-171, 2018.

[4] Mutami and A. H. DS, "Pengaruh Harga Dan Kualitas Pelayanan Terhadap Minat Beli Ulang," J. Ilmu Adm. Bisnis, vol. 7, no. 5, pp. 1-8, 2018.

[5] A. Aptaguna and E. Pitaloka, "Pengaruh Kualitas Layanan Dan Harga Terhadap Minat Beli Jasa Go-Jek," Widyakala J., vol. 3, pp. 49-56, 2016.

[6] J. Herdioko, "Pengaruh Produk Dan Harga Terhadap Minat Beli Konsumen Dalam Berbelanja Produk Kopi Secara Daring : Studi Kasus Pada Situs Internet Otten Coffee," Jrmb, vol. 12, no. 2, pp. 129-136, 2017.

[7] R. Rizki, "Pengaruh Kualitas Produk Dan Harga Terhadap Minat Beli Konsumen Produk Kosmetik Wardah," Jom Fisip, vol. 5, no. 1, pp. 1-12, 2018.

[8] A. A. Satria, "Pengaruh Harga, Promosi, dan Kualitas Produk Terhadap Minat Beli Konsumen Pada Perusahaan a-36," J. Manaj. dan Start-Up Bisnis, vol. 2, no. 1, pp. 4553, 2017.

[9] F. Septiani, "Pengaruh Harga Terhadap Minat Beli (Studi Kasus Pada Pt Asuransi Jiwa Recapital Di Jakarta)," J. Mandiri, vol. 1, no. 2, pp. 273-288, 2018.

[10] R. P. Utami and H. Saputra, "Pengaruh Harga Dan Kualitas Produk Terhadap Minat Beli Sayuran Organik Di Pasar Sambas Medan," Niagawan, vol. 6, no. 2, pp. 44-53, 2017.

[11] G. Budianto and T. Antonio, "RELAXISTER TERHADAP MINAT BELI SECARA ONLINE," J. Manaj. dan Start-Up Bisnis, vol. 3, no. 4, pp. 435-443, 2018.

[12] D. Chandra, "Pengaruh Kualitas Pelayanan Terhadap Kepuasan dan Minat Beli Konsumen di Rumah Makan Boga-Bogi Surakarta," Informatika, vol. 01, no. 02, pp. 5364, 2014.

[13] A. L. Hadani, "ANALISIS PENGARUH KUALITAS LAYANAN TERHADAP MINAT BELI ULANG (Studi Empiris Pada PT. Sriwijaya Air Distrik Semarang)," J. BIsnis Strateg., vol. 2, no. 2, pp. 128-159, 2008.

[14] S. Murwanti and Surakarta, "PENGARUH KULATIAS PELAYANAN DAN PROMOSI TERHADAP MINAT BELI ULANG JASA SERVICE MOTOR DENGAN KEPUASAN PELANGGAN SEBAGAI VARIABEL MEDIASI ( Studi Pada Bengkel Motor Ahass Cabang UMS )," Manaj. dan bisnis, vol. 9, no. 2007, pp. 207-227, 2017.

[15] N. Oktaviani, "PENGARUH KUALITAS PELAYANAN TERHADAP MINAT PEMBELIAN ULANG (Studi pada Trans Retail Carrefour di Bandung)," e-Proceeding Manaj., vol. 2, no. 3, pp. 2419-2427, 2015. 